\title{
Evaluation of Arbitrarily Primed PCR Analysis and Pulsed-Field Gel Electrophoresis of Large Genomic DNA Fragments for Identification of Enterococci Important in Human Medicine
}

\author{
P. DESCHEEMAEKER, ${ }^{1 *}$ C. LAMMENS, ${ }^{1}$ B. POT,, 2 P. VANDAMME,${ }^{1,3}$ AND H. GOOSSENS ${ }^{1}$ \\ Department of Microbiology, University Hospital Antwerp, Universitaire Instelling Antwerpen, Antwerp, ${ }^{1}$ and Laboratory \\ of Microbiology ${ }^{3}$ and BCCM/LMG Culture Collection, ${ }^{2}$ University of Ghent, Ghent, Belgium
}

\begin{abstract}
The increasing problems encountered with enterococcal nosocomial infections and the intrinsic and acquired resistance of the enterococci to different antimicrobial compounds highlight the need for a rapid identification technique. Enterococcus faecalis is readily identified by biochemical tests, but species differentiation within the Enterococcus faecium and Enterococcus gallinarum species groups is less well established. In the present study, 66 strains representing the most prevalent human enterococci were used to develop a PCR-based species-specific identification protocol. Whole-cell protein analysis by sodium dodecyl sulfate-polyacrylamide gel electrophoresis was used as a reference method for species identification. In addition, the genomic SmaI macro-restriction fragment distribution of all of the strains was examined by pulsed-field gel electrophoresis (PFGE). Oligonucleotide D11344-primed PCR was as discriminative as whole-cell protein analysis and resulted in more easily interpreted band patterns. This PCR-based technique allowed identification of clinical isolates by visual examination of the DNA profiles obtained. The inability of both methods to discriminate between Enterococcus casseliflavus and Enterococcus flavescens brought into question the species status of $E$. flavescens. PFGE did not result in species-discriminative DNA bands or band patterns, but proved to be superior for interpretation of interstrain relationships.
\end{abstract}

The incidence of nosocomial enterococcal infections has risen to an alarming extent (12). Ample examples of enterococcal endocarditis, bacteremia, urinary tract infection, and neonatal sepsis have been reported (33). Enterococcus faecium and Enterococcus faecalis are part of the intestinal and fecal flora of humans and animals $(7-9,25)$, yet they are notorious organisms in human and veterinary medicine for their inherent and acquired resistance to multiple antibiotics $(2,17)$.

Because of naturally occurring differences in susceptibility, in some cases species level identification is very important in determining the appropriate antibiotic therapy $(12,25)$, while strain-specific characterization of the bacteria has great value for epidemiologic surveillance (25). However, the phenotypic schemes currently used to identify enterococcal species fail to distinguish several species, especially species in the Enterococcus gallinarum and E. faecium species groups (6). Alternative identification protocols based on penicillin-binding protein profiles (45), bacteriolytic pattern analysis (29), and sodium dodecyl sulfate (SDS)-polyacrylamide gel electrophoresis (PAGE) of whole-cell proteins (35) have been developed. The development of new methods involving various DNA-based typing techniques has opened new perspectives for identification of clinical isolates on both the strain level and the species level. In the present study we evaluated two of these DNAbased typing techniques, namely, PCR-based DNA typing in which random or repetitive sequences are used as primers and pulsed-field gel electrophoresis (PFGE) of genomic macrorestriction fragments. Both of these identification methods have been used primarily for epidemiological surveillance of clinical isolates $(37,39,40)$, but they appeared to be useful for species level differentiation in a number of genera $(11,14,15)$. Since there is a correlation between DNA-DNA hybridization

* Corresponding author. Mailing address: Universitaire Instelling Antwerpen, Universiteitsplein 1,S3, B-2610 Wilrijk, Belgium. Phone and fax: (32)3.820.2663. E-mail: dscheem@uia.ua.ac.be. values and whole-cell protein pattern similarity levels (30), the SDS-PAGE technique was used as a reference method for enterococcal species level identification.

\section{MATERIALS AND METHODS}

Collection of strains. A total of 66 strains representing Enterococcus casselifla vus, Enterococcus durans, E. faecalis, E. faecium, Enterococcus flavescens, E. gallinarum, and Enterococcus hirae were included in all analyses (Table 1). Reference strains and field isolates were selected so that most enterococcal specie were equally represented; the only exception was $E$. flavescens, for which only four strains were available. The field isolates originated from a range of differen sources and were isolated over a long period of time. They were kindly supplied by L. A. Devriese (Faculty of Veterinary Medicine, University of Ghent, Ghent Belgium) and B. Gordts (Laboratory of Clinical Microbiology, Hospital AZ St.-Jan Brugge, Bruges, Belgium) or were our own isolates (University Hospital of Antwerp, Antwerp, Belgium). All field isolates were preliminarily identified in different laboratories by classical biochemical tests (13).

Identification of strains by SDS-PAGE. Strains were grown for $24 \mathrm{~h}$ at $37^{\circ} \mathrm{C}$ on De Man-Rogosa-Sharpe agar (Difco Laboratories, Detroit, Mich.) and were incubated in a microaerobic atmosphere containing $5 \% \mathrm{O}_{2}, 10 \% \mathrm{CO}_{2}$, and $85 \%$ $\mathrm{N}_{2}$. PAGE of whole-cell proteins, densitometric analysis, normalization and interpolation of the protein profiles, and numerical analysis were performed as described by Pot et al. (30). Strains were identified by using a database comprising protein patterns of more than 700 enterococcal strains representing all currently described species $(16,32,42)$

PFGE. All cultures were grown on Columbia agar (GIBCO, Life Technologies, Paisley, Scotland) supplemented with 5\% defibrinated horse blood and were incubated at $37^{\circ} \mathrm{C}$ in the presence of $5 \% \mathrm{CO}_{2}$. One loopful of cells from a culture that had been grown overnight was washed three times in $1 \mathrm{ml}$ of EET buffer (100 mM EDTA, $10 \mathrm{mM}$ EGTA, $10 \mathrm{mM}$ Tris- $\mathrm{HCl}[\mathrm{pH} 8.0]$; all of the reagents used were obtained from Sigma Chemical Co. unless otherwise noted) The cells were pelleted and then were resuspended in EC buffer $(6 \mathrm{mM}$ Tris-HC [pH 7.6], $1 \mathrm{M} \mathrm{NaCl}, 100 \mathrm{mM}$ EDTA [pH 8.0], $0.5 \%$ Brij 58, 0.2\% deoxycholate $0.5 \% \mathrm{~N}$-lauroylsarcosine), adjusted to a density of $4 \times 10^{9} \mathrm{CFU} / \mathrm{ml}$ by turbidimetry, mixed with an equal volume of $1.6 \%(\mathrm{wt} / \mathrm{vol})$ low-melting-point preparative grade agarose (Bio-Rad Laboratories, Nazareth, Belgium) in EC buffer, and pipetted into a plug mold. The solidified plugs were incubated overnight at $37^{\circ} \mathrm{C}$ in $0.7 \mathrm{ml}$ of EC lysis buffer ( $2.88 \mathrm{mg}$ of lysozyme per $\mathrm{ml}$ of EC buffer). The lysis buffer was replaced by $1 \mathrm{ml}$ of protein digestion buffer $(3.3 \mathrm{mg}$ of pronase $E$ per $\mathrm{ml}$ of EET buffer containing $1.6 \%$ [wt/vol] SDS), and the preparation was incubated overnight at $37^{\circ} \mathrm{C}$. Before restriction digestion, the agarose plugs were washed four times for $1 \mathrm{~h}$ in EET buffer, twice for $1 \mathrm{~h}$ in $\mathrm{T}_{10} \mathrm{E}_{0.1}$ buffer $(10 \mathrm{mM}$ Tris- $\mathrm{HCl}, 0.1 \mathrm{mM}$ EDTA [pH 8.0]), and once for $1 \mathrm{~h}$ in the appropriate restriction buffer at room temperature. Macro-restriction of the genomic DNA was carried out overnight at $25^{\circ} \mathrm{C}$ in $250 \mu \mathrm{l}$ of fresh restriction buffer containing $25 \mathrm{U}$ 
TABLE 1. Enterococcal strains used and their origins

\begin{tabular}{|c|c|c|c|c|}
\hline Species & Strain $^{a}$ & Designation as received $d^{a, b}$ & Source of isolation & Year of isolation \\
\hline \multirow[t]{10}{*}{ E. casseliflavus } & LMG $10745^{\mathrm{T}}$ & $\operatorname{ATCC} 25788^{\mathrm{T}}$ & Plant material & \\
\hline & LMG 12306 & SPE $12 b$ & Avian intestine & 1992 \\
\hline & LMG 12307 & LSC 6 & Avian intestine & 1992 \\
\hline & LMG 12309 & A 22 & Avian intestine & 1992 \\
\hline & LMG 12310 & RS $129 a$ & Bovine intestine & 1992 \\
\hline & LMG 12311 & S 289 & Equine intestine & 1992 \\
\hline & LMG 12314 & Kat 32 & Feline anus & 1992 \\
\hline & LMG 12901 & NCFB 2310 & Plant material (grass silage) & \\
\hline & LMG 14406 & PF6 & Equine manure & 1993 \\
\hline & LAB 938 & $14 / 6$ & Human feces & 1993 \\
\hline \multirow[t]{11}{*}{ E. durans } & LMG $10746^{\mathrm{T}}$ & ATCC $19432^{\mathrm{T}}$ & Dried milk & \\
\hline & LMG 12283 & SP 2 & Avian intestine & 1992 \\
\hline & LMG 12285 & SP 225 & Avian intestine & 1992 \\
\hline & LMG $12691^{\mathrm{T}}$ & CCM $5612^{\mathrm{T}}$ & Dried milk & \\
\hline & LMG 12903 & NCFB 496 & & \\
\hline & LMG $13604 \mathrm{t} 2$ & A 96 & Avian intestine & \\
\hline & LMG 14197 & 27382 & & 1993 \\
\hline & LMG 14202 & GBg22 & Fish (herring) & 1993 \\
\hline & LMG 14374 & Esc 12 & Bovine & 1993 \\
\hline & LMG 14763 & Sc. $123 \mathrm{im}$ & & Before 1950 \\
\hline & LMG 16172 & V580C & Equine feces & \\
\hline \multirow[t]{11}{*}{ E. faecalis } & LMG $7937^{\mathrm{T}}$ & DSM $20478^{\mathrm{T}}$ & & \\
\hline & LMG $9475^{c}$ & DSM 20452 & Rodent intestine (rat) & \\
\hline & LMG 11395 & DSM 20371 & Human pleural fluid & \\
\hline & LMG 11636A & $12 \mathrm{C} / \mathrm{S} 3$ & & Before 1950 \\
\hline & LMG 11734 & STR 302 & Dog & \\
\hline & LMG 13596 & Ton 609 & Pig & \\
\hline & LMG 14392 & $266 / 6974$ & Japanese nightingale intestine & \\
\hline & LMG 14409 & PF 8 & Equine manure & \\
\hline & LMG 14818t1 & STR 761 & Parakeet & \\
\hline & LMG 15073 & AL 22 & Bovine rumen (deer) & \\
\hline & LMG 16304 & PF 47 & Equine manure & \\
\hline \multirow[t]{9}{*}{ E. faecium } & LMG 8148 & CCUG 14 & Human & 1968 \\
\hline & LMG $8149^{\mathrm{T}}$ & CCUG $542^{\mathrm{T}}$ & & Before 1946 \\
\hline & LMG 9430 & ATCC 21053 & Sour milk & \\
\hline & LMG 11422 & NCFB 1632 & & \\
\hline & LMG 16164 & V 201 & Equine feces & 1993 \\
\hline & UZA $1-20$ & $\begin{array}{l}1-20 \\
1-9\end{array}$ & Human leg wound & 1993 \\
\hline & $\begin{array}{l}\text { UZA 1-9 } \\
\text { UZA 3-26 }\end{array}$ & $3-26$ & $\begin{array}{l}\text { Human blood } \\
\text { Human bile }\end{array}$ & 1993 \\
\hline & UZA $6-8$ & $6-8$ & Human anus & 1993 \\
\hline & LAB 1265 & $10-14$ & Human feces & \\
\hline \multirow[t]{4}{*}{ E. flavescens } & LMG $13518^{\mathrm{T}}$ & $\mathrm{CCM} 4239^{\mathrm{T}}$ & Human blood & 1992 \\
\hline & LMG $13597 \mathrm{t} 2$ & GBf12 & Plant material (pepper) & \\
\hline & LMG 16313 & CCUG 30568 & Human abscess & 1992 \\
\hline & LMG 16314 & CCUG 30569 & Human osteomyelitis & 1992 \\
\hline \multirow[t]{10}{*}{ E. gallinarum } & LMG 12313 & A 5 & Avian intestine & 1992 \\
\hline & LMG 12904 & NCFB 1618 & & \\
\hline & LMG $13129^{\mathrm{T}}$ & ATCC $49573^{\mathrm{T}}$ & Avian intestine & 1978 \\
\hline & LMG 14041 & MCV-3 & Human & \\
\hline & LAB 931 & UZA 4/1 & Human pus, rectum & 1993 \\
\hline & LAB 932 & UZA $9 / 4$ & Human abdominal wound & 1993 \\
\hline & LAB 933 & UZA $15 / 4$ & Human appendix & 1993 \\
\hline & LAB 1259 & $66 \mathrm{~V}$ & Human feces & \\
\hline & LAB 1261 & $9 \mathrm{~V}$ & Human feces & \\
\hline & LAB 1262 & $90 \mathrm{~V}$ & Human feces & \\
\hline \multirow[t]{6}{*}{ E. hirae } & LMG $6399^{\mathrm{T}}$ & ATCC $8043^{T}$ & & \\
\hline & LMG 11425 & NCFB 1648 & & \\
\hline & LMG 11492 & NCFB 2693 & & \\
\hline & LMG 11493 & NCFB 2708 & & 1993 \\
\hline & LMG 14200 & $\mathrm{EVF} / 87 / 152$ & Avian & 1993 \\
\hline & LMG 14201 & $2 \mathrm{CTI}$ & Avian & 1993 \\
\hline
\end{tabular}


TABLE 1-Continued

\begin{tabular}{clclc}
\hline Species & \multicolumn{1}{c}{ Strain $^{a}$} & Designation as received $^{a, b}$ & \multicolumn{1}{c}{ Source of isolation } & Year of isolation \\
\hline & LMG 14260 & Esc 110T & & 1994 \\
& LMG 14488 & PF 12 & Equine feces & 1994 \\
& LMG 14489 & $94 / 290$ & Avian (parrot spleen) & 1993 \\
\hline LAB 937 & UZA 16/3 & Human postoperative wound & 1993 \\
\hline
\end{tabular}

${ }^{a}$ LMG, Culture Collection, Laboratorium voor Microbiologie, Universiteit Gent, Ghent, Belgium; LAB, Lactic Acid Bacteria Culture Collection, Laboratorium voor Microbiologie, Universiteit Gent, Ghent, Belgium; UZA, Universitair Ziekenhuis Antwerpen, Culture Collection of the University Hospital Antwerp, Antwerp, Belgium.

${ }^{b}$ Culture collection strains were obtained from the following international culture collections: ATCC, American Type Culture Collection, Rockville, Md.; CCUG, Culture Collection of the University of Göteborg, Department of Clinical Bacteriology, University of Göteborg, Göteborg, Sweden; NCFB, National Collection of Food Bacteria; CCM, Czechoslovak Collection of Microorganisms, Brno, Czech Republic; DSM, Deutsche Sammlung von Mikroorganismen, Braunschweig, Germany. Strains without culture collection designations are our own isolates.

Originally received as the type strain of Lactobacillus murinus.

of SmaI (MBI Fermentas, St. Leon-Rot, Germany). The digestion reaction wa stopped by adding $0.5 \mathrm{ml}$ of $0.5 \mathrm{M}$ EDTA ( $\mathrm{pH} 8.0$ ), and the plugs were stored a $4^{\circ} \mathrm{C}$. The chromosomal restriction fragments were separated by PFGE in a contour-clamped homogeneous electric field MAPPER system (Bio-Rad Laboratories) by loading pieces of the plugs ( 2 by 5 by $0.5 \mathrm{~mm}$ ) into the wells of a $1 \%$ (wt/vol) Pulsed Field Certified Agarose (Bio-Rad Laboratories) gel that was prepared in $0.5 \times$ TBE ( $45 \mathrm{mM}$ Tris- $\mathrm{HCl}, 45 \mathrm{mM}$ boric acid, $1 \mathrm{mM}$ EDTA) and sealed with the same agarose. Electrophoresis was performed in a level electrophoresis chamber containing 2 liters of $0.5 \times$ TBE equilibrated at $14^{\circ} \mathrm{C}$ at constant voltage of $6 \mathrm{~V} / \mathrm{cm}$, with pulse times ramping linearly from 5 to $35 \mathrm{~s}$ for 24 h.

The SmaI-digested genome of Staphylococcus aureus NCTC 8325 (37) was used both as a molecular size standard and as an intrinsic gel normalization standard. This standard was prepared by the procedures described above except that lysozyme was replaced by lysostaphin $(100 \mu \mathrm{g} / \mathrm{ml}$ of EC buffer $)$

Typically, each pulsed-field gel consisted of 15 DNA patterns, 3 of which were the normalization standard. The DNA band profiles were stained with ethidium bromide, visualized, and digitized by the Gel Doc 1000 documentation system (Bio-Rad Laboratories). Conversion, normalization, and further analysis of the patterns were performed by using the GelCompar software, version 3.1b (Applied Maths, Kortrijk, Belgium) as described previously $(30,43)$. The levels of similarity between different PFGE patterns were calculated by using the Dice coefficient (10), and correlation coefficients were calculated by the unweighted pair group method with arithmetic averages.

PCR-based typing. DNA was prepared by using the rapid procedure described by Pitcher et al. (27). Two repetitive primers (ERIC 1R and ERIC 2) (44) and three random primers (D14307, D11344, and D8635) (1) were evaluated for their suitability to differentiate enterococci. DNA amplification was performed with a DNA thermal cycler (model 9600 GeneAmp PCR system; Perkin-Elmer Zaventem, Belgium). Each 100- $\mu$ I PCR mixture contained $50 \mathrm{mM} \mathrm{KCl}, 10 \mathrm{mM}$ Tris- $\mathrm{HCl}$ (pH 9.0), $2.5 \mathrm{mM} \mathrm{MgCl}, 0.1 \%$ Triton X-100, $0.01 \%$ gelatin, $0.2 \mathrm{mM}$ deoxynucleoside triphosphates, 50 pmol of primer ERIC 1R or ERIC 2 or 100 pmol of primer D14307, D11344, or D8635, 0.6 U of Goldstar polymerase (Eurogentec, Seraing, Belgium), and $100 \mathrm{ng}$ of extracted DNA. When prime ERIC 1R or ERIC 2 was used, 40 cycles were performed, each consisting of 1 min of denaturation at $94^{\circ} \mathrm{C}, 1 \mathrm{~min}$ of annealing at $25^{\circ} \mathrm{C}$, and 2 min of elongation at $74^{\circ} \mathrm{C}$. With primers D14307, D11344, and D8635 the amplification process was as follows: an initial four cycles consisting of denaturation at $94^{\circ} \mathrm{C}$ for $5 \mathrm{~min}$ annealing at $40^{\circ} \mathrm{C}$ for $5 \mathrm{~min}$, and elongation at $72^{\circ} \mathrm{C}$ for $5 \mathrm{~min}$, followed by 30 cycles consisting of denaturation at $94^{\circ} \mathrm{C}$ for $1 \mathrm{~min}$, annealing at $55^{\circ} \mathrm{C}$ for $1 \mathrm{~min}$, and elongation at $72^{\circ} \mathrm{C}$ for $2 \mathrm{~min}$, followed by one cycle consisting of $10 \mathrm{~min}$ at $72^{\circ} \mathrm{C}$.

After amplification, $25 \mu \mathrm{l}$ of the amplicon was mixed with $7 \mu \mathrm{l}$ of loading buffer (50\% glycerol, $0.8 \mathrm{mg}$ of bromophenol blue per $\mathrm{ml}$ ) and electrophoresed in a $1.5 \%$ pronarose D1 gel (Sphaero Q, Burgos, Spain) for $3 \mathrm{~h}$ at $100 \mathrm{~V}$ in $0.5 \times \mathrm{TBE}$ containing $0.05 \mathrm{mg}$ of ethidium bromide per liter.

The normalization standard, which was applied three times to each gel (the gels contained a maximum of 16 lanes), was the amplification product of $E$. faecium LAB 1265 obtained with primer D14307. Image acquisition and computer analysis were performed as described above for PFGE data acquisition. The levels of similarity between different PCR band patterns were calculated by using the Pearson product moment correlation coefficient $(r)$ (34).

\section{RESULTS}

SDS-PAGE. Multiple strains were cultured several times to check the reproducibility of both the protein extraction procedure and the electrophoresis technique. The average $r$ value for duplicate electropherograms was more than 0.95 . The $r$ value for reproducibility of the normalization standard was more than 0.95 .
After a numerical analysis of the 66 protein electropherograms was performed, six distinct clusters were delineated, as shown in Fig. 1. The reference strains of most of the species grouped in separate clusters; the only exceptions were the $E$. casseliflavus and $E$. flavescens strains, which belonged to the same cluster. Most of the field isolates, which originally were identified by biochemical tests (data not shown), grouped in the appropriate clusters; the only exceptions were isolates LMG 12306, LMG 12307, and LMG 12314, which originally were identified as E. mundtii, E. mundtii, and E. gallinarum, respectively, which grouped in the $E$. casseliflavus-E. flavescens cluster.

Visual inspection of the electropherograms (data not shown) revealed almost identical electrophoretic protein profiles within each cluster, including the E. casseliflavus-E. flavescen cluster. The lowest $r$ value between different clusters was more than 0.75 .

PCR-based typing. The overall $r$ value for reproducibility of the PCR assay and the running conditions, as estimated by an analysis of duplicate DNA extracts of several strains, was greater than 0.92 .

Purified DNAs of all strains were examined in five PCR analyses, and in each analysis a single primer was used. A numerical analysis of the DNA band patterns obtained with each primer was performed. Figure 1 shows the dendrogram obtained with primer D11344 (5'-AGTGAATTCGCGGTGA GATGCCA- $3^{\prime}$ ). The reference strains and field isolates of $E$. durans, E. faecalis, E. faecium, E. gallinarum, and E. hirae grouped in well-separated clusters, while the $E$. casseliflavus and $E$. flavescens strains formed a single cluster. The differences in the band patterns of the different clusters were substantial (Fig. 2). Visual inspection of the DNA band patterns within each of the clusters revealed small differences between most strains. The level of similarity ( $r$ value) between different clusters was always less than 0.40 (Fig. 1).

When primer D14307 (5'-GGTTGGGTGAGAATTGCAC G-3') was used, only the E. gallinarum strains were unequivocally identified at the species level by the presence of one unique amplimer (data not shown). Strains of the other species were not identified at the species level. Primers D8635, ERIC $1 \mathrm{R}$, and ERIC 2 generated very diverse DNA band patterns for each of the species and proved to be useful for strain discrimination but not for species differentiation.

PFGE. The reproducibility between different restriction digests and electrophoretic runs for the same genome was $100 \%$, as determined by the Dice coefficient (data not shown).

In general, SmaI produced 13 to 23 distinct genomic DNA fragments in all of the strains studied. Cluster analysis and visual inspection of the restriction profiles obtained revealed that the following strains had identical patterns: LMG 16313 , 


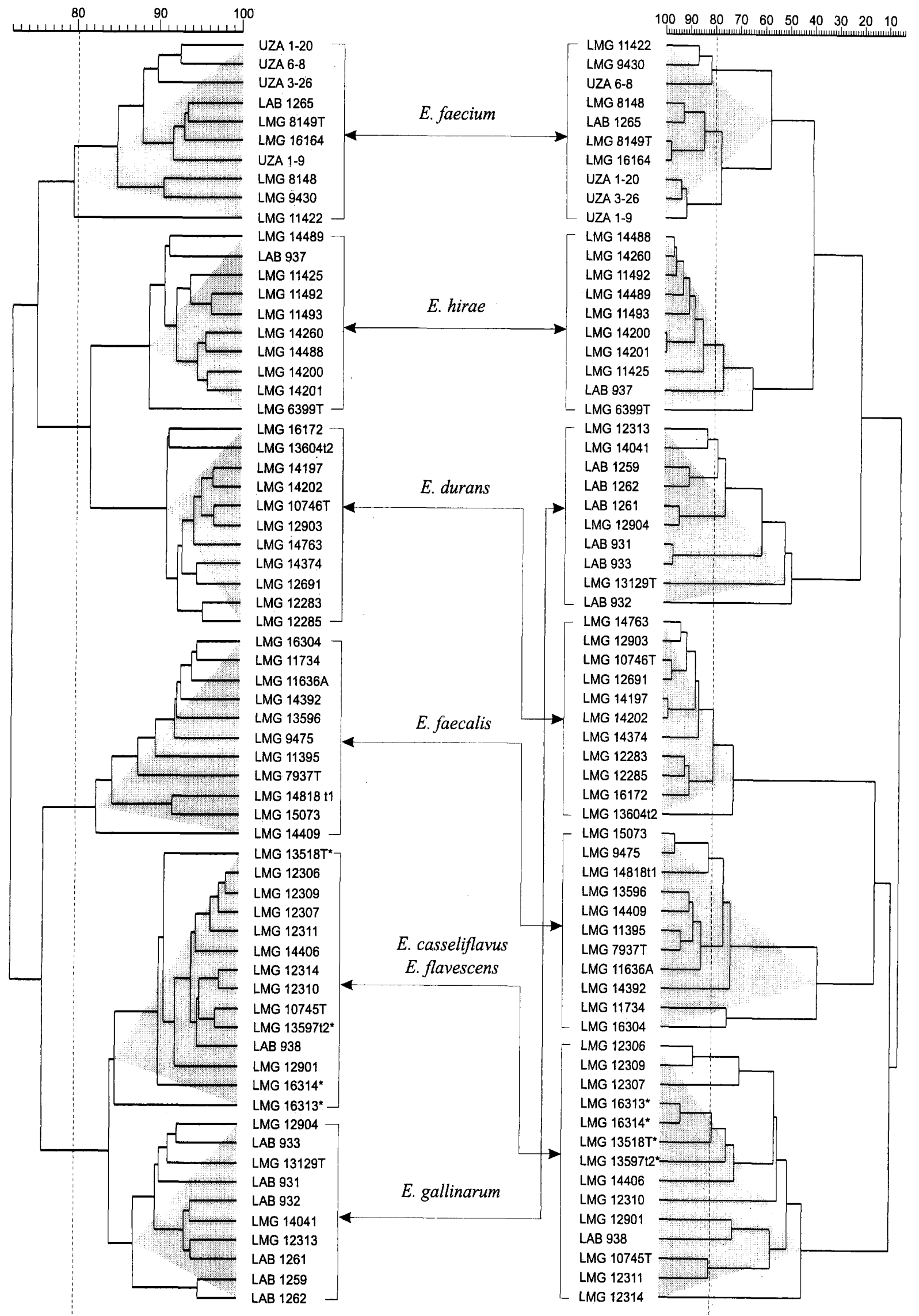

FIG. 1. Dendrograms derived from unweighted pair group average linkage of $r$ values for protein electropherograms (left side) and D11344-primed PCR patterns (right side) of 66 enterococcal strains. E. flavescens strains are indicated by asterisks. The vertical dotted line indicates the $80 \%$ similarity level for comparative purposes. 


\section{$\begin{array}{lllllllllllll}1 & 2 & 3 & 4 & 5 & 6 & 7 & 8 & 9 & 10 & 11 & 12 & 131415\end{array}$}

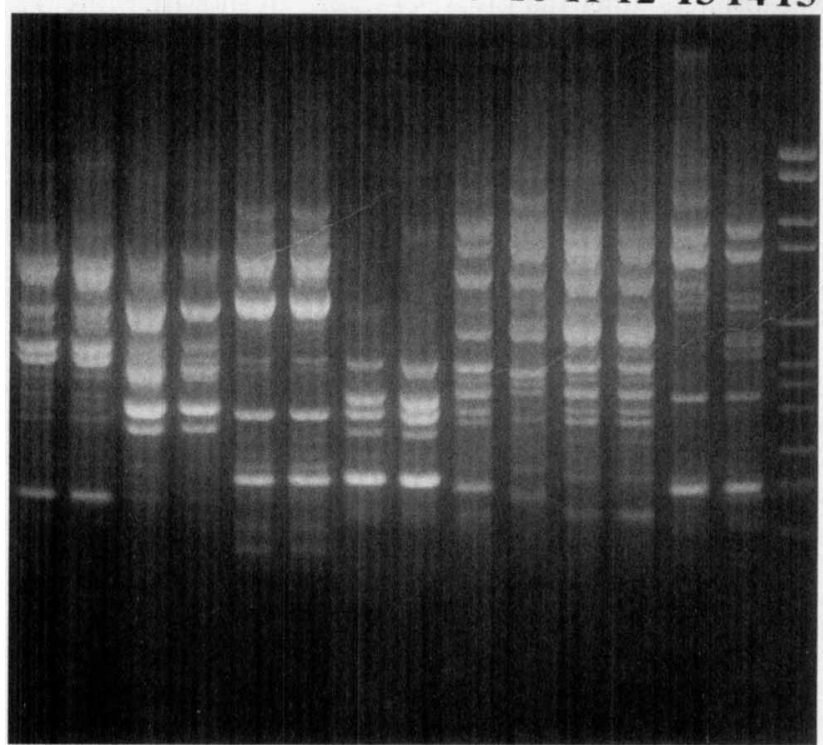

FIG. 2. DNA amplification patterns obtained with primer D11344 for $E$ durans LMG $10746^{\mathrm{T}}$ (lane 1) and LMG $12691^{\mathrm{T}}$ (lane 2), E. hirae LMG 14201 (lane 3) and LMG 14200 (lane 4), E. faecium LMG $8149^{\mathrm{T}}$ (lane 5) and LMG 16164 (lane 6), E. gallinarum LAB 933 (lane 7) and LAB 931 (lane 8), E casseliflavus LAB 938 (lane 9) and LMG 12309 (lane 10), E. flavescens LMG 16314 (lane 11) and LMG 16313 (lane 12), and E. faecalis LMG 11395 (lane 13) and LMG $7937^{\mathrm{T}}$ (lane 14). The molecular weight marker (lane 15) (catalog no 1062590; Boehringer Mannheim) contained 154-, 220-, 234-, 298-, 394-, 453-, 517-, 653-, 1,033-, 1,230-, 1,766-, and 2,176-bp double-stranded DNA fragments.

LMG 16314, and LMG $13518^{\mathrm{T}}(\mathrm{T}=$ type strain) (E. flavescens); LMG 14200 and LMG 14201 (E. hirae); LMG $12691^{\mathrm{T}}$ and LMG $10746^{\mathrm{T}}$ (E. durans); and LMG 11492 and LMG 11493 (E. hirae). LAB 1259 and LAB 1262 (E. gallinarum) were identified as closely related strains that conformed to the definition of Tenover et al. (37). After numerical comparison, species-specific clusters were not obtained, although several $E$. gallinarum strains grouped together because of the presence of multiple poorly resolved bands in the lower fragment region $(<200 \mathrm{~kb})$ (data not shown).

\section{DISCUSSION}

Enterococci were traditionally considered to be endogenous in origin and not primary pathogens (17). However, these organisms are well-known opportunistic secondary pathogens which are difficult to eradicate because of their inherent and acquired resistance to several antibiotics. With this perspective, $E$. faecalis and $E$. faecium have recently gotten much attention because of their high levels of resistance to several antimicrobial agents, including glycopeptides. Controlling the spread of such multiply resistant organisms is very important $(25,38)$. PFGE is considered the molecular typing tool of choice for identification of clonal outbreaks (37). However, with certain infections, especially endocarditis, proper identification of enterococci to the species level is important because of species-specific differences in susceptibility to $\beta$-lactam antibiotics and glycopeptides (24). E. faecalis is easily differentiated from other enterococci by its tolerance to $0.04 \%$ tellurite (13). However, biochemical differentiation between $E$. faecium, E. durans, and E. hirae on the one hand and E. gallinarum, E. casseliflavus, and E. flavescens on the other hand is very difficult because of the overlap in phenotypic characteristics (6).

In the present study we evaluated PCR-based DNA typing and genome macro-restriction fragment analysis for their ability to identify strains belonging to these species at the species level. Reference strains and several field isolates, identified by biochemical tests, were chosen so that each of the species was represented equally. For $E$. flavescens, only four strains were included. Strains that had various origins and were isolated over a long period of time were selected in order to obtain a diverse collection.

Whole-cell protein electrophoresis as identification standard. Within many gram-positive and gram-negative genera, there is agreement between the results obtained in DNA-DNA hybridization experiments and the results obtained by wholecell protein electrophoresis (41). Indeed, for the most part strains with very similar whole-cell protein patterns exhibit high levels of DNA homology and therefore belong to the same species $(3,18-20,31,35)$. Teixeira et al. (35) demonstrated that this agreement exists in the genus Enterococcus as well. We therefore used SDS-PAGE of whole-cell proteins as the reference method for species level identification (5).

PCR-based typing. As a first approach, 27 different oligonucleotides were evaluated to determine their suitability to type a restricted set of Enterococcus strains (4). In the present study, the following five primers were used to examine all of the strains: random primers D11344, D14307, and D8635, which were originally used to type Helicobacter pylori strains (1), and repetitive primers ERIC $1 \mathrm{R}$ and ERIC $2(22,44)$. A single primer, D11344, proved to be useful for species-specific characterization. A second primer, D14307, allowed straightforward identification of all E. gallinarum strains by the presence of one unique dense amplimer. However, species-specific characterization of the other strains was not possible. Finally, primers D8635, ERIC 1R, and ERIC 2 did not produce speciesspecific band patterns, but primer D8635 was useful for characterization of individual strains (data not shown).

Numerical analysis of the D11344-primed band patterns and whole-cell protein analysis revealed identical clusters of strains (Fig. 1). The reproducibility of the PCR technique was somewhat lower $(r=0.92)$ than the reproducibility of the SDSPAGE technique $(r>0.95)$; this was mainly due to the less reproducible PCR technique (23). Because of the extremely low levels of similarity between the different clusters (Fig. 1), this lower reproducibility did not influence the identification results. Each DNA band pattern is characterized by several dense bands which are present in all of the strains of the same species. Interstrain variation was observed only in the minor bands (Fig. 2). The DNA band patterns of E. casseliflavus (Fig. 2, lanes 9 and 10) and E. flavescens (Fig. 2, lanes 11 and 12) are similar and contain no species-specific dense bands.

Because of the simplicity of the DNA band patterns, visual interpretation and, consequently, identification of unknown enterococcal isolates by the PCR technique are feasible. In contrast, the electrophoretic protein profiles of the different species are complex and fairly similar (data not shown), making visual comparisons of the profiles difficult and dependent on the experience of the researcher. With this technique, computer-based image acquisition and analysis are virtually indispensable, although suitable equipment is not widely available in routine laboratories.

PFGE. Visual comparison of all of the contour-clamped homogeneous electric field electrophoresis patterns confirmed the tendencies found in the $S m a$ I restriction fragment patterns described by Donabedian et al. (11), in which E. faecalis strains were characterized by always having their largest fragment 


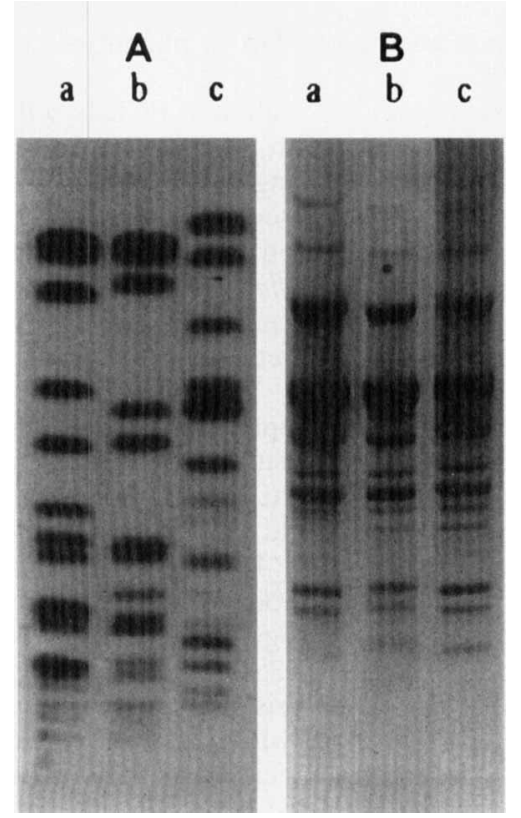

FIG. 3. Discrepancy between the PFGE patterns of three E. faecium strains (A) and the D8635-primed PCR patterns of the same strains (B). Identical PCR patterns did not necessarily result in identical PFGE patterns. Lane a, E. faecium LMG 16164; lane b, E. faecium LMG 8148 ; lane c, E. faecium LMG 8149.

larger than $400 \mathrm{~kb}$ and E. gallinarum strains were characterized by having all of their $S m a \mathrm{I}$ fragments smaller than $200 \mathrm{~kb}$. This was not obvious when the fragment distribution in the SmaI pulsed-field patterns of a large number of strains was studied. For example, E. gallinarum strains were indeed characterized by having their largest $S m a$ I fragment always smaller than 200 $\mathrm{kb}(11)$, but several $E$. casseliflavus strains also had this characteristic. In $E$. hirae and $E$. durans strains, as well as in $E$. faecalis (11), the largest SmaI fragment was larger than $400 \mathrm{~kb}$ (11). As expected, a numerical analysis of the PFGE patterns obtained revealed no species-specific band patterns. Only the PFGE patterns of several E. gallinarum strains grouped together due to multiple poorly resolved bands in the smallfragment region. Other electrophoretic conditions should be considered for optimal electrophoretic separation of SmaI restriction fragments of E. gallinarum strains, as proposed by Donabedian et al. (11).

Although not valuable for species differentiation, PFGE appeared to be superior for interpretation of interstrain relationships, which confirmed numerous previous reports $(21,24,38)$. The identical PFGE patterns obtained were confirmed by identical PCR patterns, independent of the primer used. However, identical PCR patterns did not necessarily result in identical PFGE patterns (Fig. 3).

E. casseliflavus and $E$.flavescens. Neither protein analysis nor PCR-based typing was able to differentiate between $E$. casseliflavus and E. flavescens. Several authors have previously noted the striking similarities between these species. When the glycopeptide resistance genotypes were studied, the two species could not be differentiated (12). Furthermore, the high level of similarity between the ligase genes of $E$. casseliflavus and E. flavescens was described by Navarro and Courvalin (26) as not being consistent with assigning clinical isolates of $E$. casseliflavus and E. casseliflavus to two different species. Surprisingly, three of the four strains studied by Pompei et al. (28) are highly related organisms (if not a single clone), as demonstrated by the identical profiles generated in the SmaI restric- tion analysis and the PCR-based typing analysis performed with primers other than D11344 (data not shown). Moreover, the results of recently conducted DNA reassociation experiments demonstrated that $E$. flavescens and $E$. casseliflavus constitute a single species (36) and are in contrast to the DNADNA hybridization values reported by Pompei et al. (28). Phenotypically, E. flavescens differs from E. casseliflavus in its negative ribose reaction and its failure to produce alpha-hemolysis on sheep blood (28). These data suggest that $E$. flavescens should be considered an E. casseliflavus biovar rather than a separate species.

In conclusion, PCR in which primer D11344 was used was as discriminative at the species level as SDS-PAGE analysis of whole-cell proteins. In addition, the former method is technically less demanding, and identification of strains by visual examination is feasible. Like the results of other studies (12, 26,36 ), our data do not support the species status of $E$. flavescens. PFGE proved to be superior for differentiation of individual strains but generated little information at the species level.

\section{ACKNOWLEDGMENTS}

P.V. is indebted to the National Fund for Scientific Research (Belgium) for a position as a postdoctoral research fellow.

We thank all depositors of strains examined.

\section{REFERENCES}

1. Akopyanz, N., N. O. Bukanov, T. U. Westblom, S. Kresovich, and D. E. Berg. 1992. DNA diversity among clinical isolates of Helicobacter pylori detected by PCR-based RAPD fingerprinting. Nucleic Acids Res. 20:5137-5142.

2. Bates, J., J. Z. Jordens, and D. T. Griffiths. 1994. Farm animals as putative reservoir for vancomycin-resistant enterococcal infection in man. J. Antimicrob. Chemother. 34:507-514.

3. Costas, M. 1992. Classification, identification, and typing of bacteria by the analysis of their one-dimensional polyacrylamide gel electrophoretic protein patterns, p. 351-408. In A. Chambrach, M. J. Dunn, and B. J. Radola (ed.), Advances in electrophoresis, vol. 5. VCH Verlagsgesellschaft, Weinheim, Germany.

4. Descheemaeker, P., and C. Lammens. 1995. Unpublished data.

5. Devriese, L. A., B. Pot, L. Van Damme, K. Kersters, and F. Haesebrouck. 1995. Identification of Enterococcus species isolated from foods of animal origin. Int. J. Food Microbiol, 26:187-197.

6. Devriese, L. A., B. Pot, and M. D. Collins. 1993. Phenotypic identification of the genus Enterococcus and differentiation of phylogenetically distinct enterococcal species and species groups. J. Appl. Bacteriol. 75:399-408.

7. Devriese, L. A., J. Hommez, B. Pot, and F. Haesebrouck. 1994. Identification and composition of the streptococcal and enterococcal flora of tonsils, in testines and faeces of pigs. J. Appl. Bacteriol. 77:31-36.

8. Devriese, L. A., J. Hommez, R. Wijfels, and F. Haesebrouck. 1991. Composition of the enterococcal and streptococcal intestinal flora of poultry. J. Appl. Bacteriol. 71:46-50.

9. Devriese, L. A., L. Laurier, P. Herdt, and F. Haesebrouck. 1992. Enterococcal and streptococcal species isolated from faeces of calves, young cattle and dairy cows. J. Appl. Bacteriol. 72:29-31.

10. Dice, L. R. 1945. Measure of the amounts of ecological association between species. Ecology 26:297-302.

11. Donabedian, S., J. W. Chow, D. M. Shlaes, M. Green, and M. J. Zervos. 1995 DNA hybridization and contour-clamped homogeneous electric field electrophoresis for identification of enterococci to the species level. J. Clin. Microbiol. 33:141-145.

12. Dutka-Malen, S., S. Evers, and P. Courvalin. 1995. Detection of glycopeptide resistance genotypes and identification to the species level of clinically relevant enterococci. J. Clin. Microbiol. 33:24-27.

13. Facklam, R. R., and M. D. Collins. 1989. Identification of Enterococcus species isolated from human infections by a conventional test scheme. J. Clin. Microbiol. 27:731-734.

14. Giesendorf, B., A. van Belkum, A. Koeken, H. Stegeman, M. H. C. Henkens, J. Van der Plas, H. Goossens, H. G. M. Niesters, and W. G. V. Quint. 1993 Development of species-specific DNA probes for Campylobacter jejuni, Campylobacter coli, and Campylobacter lari by polymerase chain reaction fingerprinting. J. Clin. Microbiol. 31:1541-1546.

15. Giesendorf, B. A. J., W. G. V. Quint, P. Vandamme, and A. van Belkum. 1996. Generation of DNA probes for detection of microorganisms by polymerase chain reaction fingerprinting. Zentralbl. Bakteriol. Parasitenkd. In fektionskr. Hyg. Abt. 1 Orig. 283:417-430. 
16. Gordts, B., H. Van Landuyt, M. Ieven, P. Vandamme, and H. Goossens. 1995. Vancomycin-resistant enterococci colonizing the intestinal tract of hospitalized patients. J. Clin. Microbiol. 33:2842-2846.

17. Hall, L. M. C. 1993. Recent advances in understanding the epidemiology of enterococci. Rev. Med. Microbiol. 4:192-197.

18. Hertel, C., W. Ludwig, B. Pot, K. Kersters, and K. H. Schleifer. 1993. Differentiation of lactobacilli occurring in fermented milk products by using oligonucleotide probes and electrophoretic protein profiles. Syst. Appl. Microbiol. 14:463-467.

19. Heyndrickx, M., K. Vandemeulebroecke, B. Hoste, P. Janssen, K. Kersters, P. De Vos, N. A. Logan, N. Ali, and R. C. W. Berkeley. 1996. Reclassification of Paenibacillus (formerly Bacillus) pulvifaciens (Nakamura 1984) Ash et al. 1994, a later subjective synonym of Paenibacillus (formerly Bacillus) lanae (White 1906) Ash et al. 1994, as a subspecies of $P$. larvae, with emended description of $P$. larvae and $P$. larvae subsp. larvae and $P$. larvae subsp. pulvifaciens. Int. J. Syst. Bacteriol. 46:270-279.

20. Heyndrickx, M., K. Vandemeulebroecke, P. Scheldeman, B. Hoste, K. Kersters, P. De Vos, N. A. Logan, A. M. Aziz, N. Ali, and R. C. W. Berkeley. 1995 Paenibacillus (formerly Bacillus) gordonae (Pichinoty et al. 1986) Ash et al. 1994 is a later subjective synonym of Paenibacillus (formerly Bacillus) validus (Nakamura 1984) Ash et al. 1994: emended description of $P$. validus. Int. J. Syst. Bacteriol. 45:661-669.

21. Kühn, I., L. G. Burman, S. Haeggman, K. Tullus, and B. E. Murray. 1995. Biochemical fingerprinting compared with ribotyping and pulsed-field gel electrophoresis of DNA for epidemiological typing of enterococci. J. Clin. Microbiol. 33:2812-2817.

22. Lupski, J. R., and G. M. Weinstock. 1992. Short, interspersed repetitive DNA sequences in prokaryotic genomes. J. Bacteriol. 174:4525-4529.

23. Meunier, J.-R., and P. A. D. Grimont. 1993. Factors affecting reproducibility of random amplified polymorphic DNA fingerprinting. Res. Microbiol. 144: 373-379.

24. Miranda, A. G., K. V. Singh, and B. E. Murray. 1991. DNA fingerprinting of Enterococcus faecium by pulsed-field gel electrophoresis may be a useful epidemiologic tool. J. Clin. Microbiol. 29:2752-2757.

25. Murray, B. E. 1990. The life and times of the Enterococcus. Clin. Microbiol. Rev. 3:46-65.

26. Navarro, F, and P. Courvalin. 1994. Analysis of genes encoding D-alanineD-alanine ligase-related enzymes in Enterococcus casseliflavus and Enterococcus flavescens. Antimicrob. Agents Chemother. 38:1788-1793.

27. Pitcher, D. G., N. A. Saunders, and R. J. Owen. 1989. Rapid extraction of bacterial genomic DNA with guanidium thiocyanate. Lett. Appl. Microbiol. 8:151-156.

28. Pompei, R., R. Berlutti, M. C. Thaller, A. Ingianni, G. Cortis, and B. Dainelli. 1992. Enterococcus flavescens sp. nov., a new species of enterococci of clinical origin. Int. J. Syst. Bacteriol. 42:365-369.

29. Pompei, R., M. C. Thaller, F. Pittaluga, O. Flore, and G. Satta. 1992. Analysis of bacteriolytic activity patterns, a novel approach to the taxonomy of enterococci. Int. J. Syst. Bacteriol. 42:37-43.

30. Pot, B., P. Vandamme, and K. Kersters. 1994. Analysis of electrophoretic whole-organism protein fingerprints, p. 493-521. In M. Goodfellow and A. G. O'Donnell (ed), Modern microbial methods. Chemical methods in prokaryotic systematics. J. Wiley and Sons Ltd., Chichester, United Kingdom.
31. Pot, B., C. Hertel, W. Ludwig, P. Descheemaeker, K. Kersters, and K. H. Schleifer. 1993. Identification and classification of Lactobacillus acidophilus $L$. gasseri, and $L$. johnsonii strains by SDS-PAGE and rRNA-targeted oligonucleotide probe hybridisations. J. Gen. Microbiol. 139:513-517.

32. Pot, B., and D. Janssens. 1993. The potential role of a culture collection for identification and maintenance of lactic acid bacteria, p. 81-87. In E. L. Foo, H. G. Griffin, R. Möllby, and C. G. Hedén (ed.), The lactic acid bacteria. Proceedings of the First Lactic Acid Bacteria Computer Conference. Horizon Scientific Press, Norfolk, England.

33. Schaberg, D. R., D. H. Culver, and R. P. Gaynes. 1991. Major trends in the microbial etiology of nosocomial infection. Am. J. Med. 91(Suppl. 3B): 72S$75 \mathrm{~S}$

34. Sneath, P. H. A., and R. R. Sokal. 1973. Numerical taxonomy: the principles and practice of numerical classification. W. H. Freeman, San Francisco, Calif.

35. Teixeira, L. M., R. R. Facklam, A. G. Steigerwalt, N. E. Pigott, v. L. C Merquior, and D. J. Brenner. 1995. Correlation between phenotypic characteristics and DNA relatedness within Enterococcus faecium strains. J. Clin. Microbiol. 33:1520-1523.

36. Teixeira, L. M., S. Carvalho, L. C. Merquior, A. G. Steigerwalt, M. M. Teixeira, J. Brenner, and R. R. Facklam. 1996. Recent approaches on the taxonomy of the enterococci and some related microorganisms, poster P283. In Abstracts of the XIIIth Lancefield International Symposium on Streptococci and Streptococcal Diseases, September 16-20, 1996, Paris, France. ORANE Communication Graphique, Montreuil-Sous-Bois, France.

37. Tenover, F. C., R. D. Arbeit, R. V. Goering, P. A. Mickelsen, B. E. Murray, D. H. Persing, and B. Swaminathan. 1995. Interpreting chromosomal DNA restriction patterns produced by pulsed-field gel electrophoresis: criteria for bacterial strain typing. J. Clin. Microbiol. 33:2233-2239.

38. Tomayko, J. F., and B. E. Murray. 1995. Analysis of Enterococcus faecalis isolates from international sources by multilocus enzyme electrophoresis and pulsed-field gel electrophoresis. J. Clin. Microbiol. 33:2903-2907.

39. van Belkum, A. 1994. DNA fingerprinting of medically important microorganisms by use of PCR: a literature review. Clin. Microbiol. Rev. 7:174-184.

40. van Belkum, A., R. Bax, P. J. C. van der Straaten, W. G. V. Quint, and E Veringa. 1994. PCR fingerprinting for epidemiological studies of Staphylococcus aureus. J. Microbiol. Methods 20:235-247.

41. Vandamme, P., B. Pot, M. Gillis, P. De Vos, K. Kersters, and J. Swings. 1996 Polyphasic taxonomy, a consensus approach to bacterial systematics. Microbiol. Rev. 60:407-438.

42. Vandamme, P., E. Vercauteren, C. Lammens, N. Pensart, M. Ieven, B. Pot, R. Leclerq, and H. Goossens. 1996. Survey of enterococcal susceptibility patterns in Belgium. J. Clin. Microbiol. 34:2572-2576.

43. Vauterin, L., and P. Vauterin. 1992. Computer-aided objective comparison of electrophoresis patterns for grouping and identification of microorganisms. Eur. Microbiol. 1:37-41.

44. Versalovic, J., T. Koeuth, and J. R. Lupski. 1991. Distribution of repetitive DNA sequences in eubacteria and application to fingerprinting of bacterial genomes. Nucleic Acids Res. 19:6823-6831.

45. Williamson, R., L. Gutmann, T. Horaud, F. Delbos, and J. F. Acar. 1986. Use of penicillin-binding proteins for the identification of enterococci. J. Gen. Microbiol. 132:1929-1937. 